\title{
Effect of Fly Ash and Phosphorus Levels on Growth and Productivity of Raya (Brassica juncea L.)
}

\author{
Lovedeep Singh and Balwinder Singh Dhillon*
}

College of Agriculture, Guru Kashi University, Talwandi Sabo, Punjab, India

*Corresponding author

\section{A B S T R A C T}

\section{Keywords}

Fly ash,

Phosphorus, Raya, Seed yield, Siliquae and Stover yield

\section{Article Info}

Accepted:

04 September 2020

Available Online:

10 October 2020
The field experiment entitled "Effect of fly ash and phosphorus levels on growth and seed yield of raya (Brassica juncea L.) in south-west Punjab" was conducted during the rabi season 2018-2019 at Experimental Farm, Guru Kashi University, Talwandi Sabo, Bathinda (Punjab). The experiment was laid out in split plot design comprising of two levels of fly ash $(0$ and $10 \mathrm{t} / \mathrm{ha})$ in main plot and four phosphorus levels $\left(0,15,30\right.$ and $\left.45 \mathrm{~kg} \mathrm{P}_{2} \mathrm{O}_{5} / \mathrm{ha}\right)$ in sub plot. The results showed that application of 10 t/ha fly ash gave significantly maximum seed yield (2362 kg/ha) and increase was $6.8 \%$ over control. The application of phosphorus increased the seed yield of raya and the maximum seed yield $(2489 \mathrm{~kg} / \mathrm{ha})$ was recorded with $45 \mathrm{~kg} \mathrm{P}_{2} \mathrm{O}_{5} /$ ha application. These increase in seed yield was 29.1, 7.7 and $3.1 \%$ over control, 15 and $30 \mathrm{kgP}_{2} \mathrm{O}_{5} /$ ha respectively. Similar trend was observed in case of stover yield. Application of fly ash resulted in significant increasing growth parameters i.e. number of branches per plant (13.2), leaf area index (4.26) and dry matter accumulation (87.1 q/ha) of raya. Similarly, yield attributes i.e. number of siliquae per plant (404.5), number of seeds per siliqua (12.3) and test weight (4.2 gm) was higher with fly ash application than control. Application of phosphorus at the rate of $45 \mathrm{~kg} \mathrm{P}_{2} \mathrm{O}_{5} / \mathrm{ha}$ significantly increased the plant height $(191.7 \mathrm{~cm})$ and dry matter accumulation $(90.2$ $\mathrm{q} / \mathrm{ha}$ ), number of siliquae per plant (417.2) and number of seeds per siliqua (12.5) as compared to other levels of phosphorus.

\section{Introduction}

Raya (Brassica juncea L.) is most important edible oil seed crop of the world and rank third after soybean and oil-palm. In India, oilseeds constitute the second largest agriculture commodity after cereals accounting for nearly 5\% of gross national product and $10 \%$ of the value of all agriculture products. Being one of the leading oilseed producing country, India is not able to meet the edible requirement for its ever growing vast population. Among the oilseeds, rapeseed-mustard contribute nearly $21.6 \%$ and $23.1 \%$ to the total oilseed area and production, respectively. A considerable decrease in productivity of oilseeds from $1,750 \mathrm{~kg} / \mathrm{ha}$ in $2006-2007$ to $1,188 \mathrm{~kg} / \mathrm{ha}$ in 2013-2014 has been noticed in spite of increase in production and from 46.27 million tonnes in 2006-2007 to 63.09 million tonnes in the 2013-2014 (DRMR, 2013-2014). In 
Punjab, rapeseed and mustard were cultivated in the area of 30.5 thousand hectares with a production of 45.7 thousand tonnes and average yield 14.98 quintals per hectare during 2017-18. (Anonymous, 2019)

Fly ash is the end product residue left after the combustion of pulverized bituminous or nonbituminous coal in the thermal power plants and consists of mineral constituents which is not fully burnt. In India, use of fly ash is low as compared to developed countries due to non-availability of cost effective technology. The increase in crop yield with fly ash application may be attributed to the availability of soil water and nutrient content in addition to its impact on soil health.

The high yielding varieties of raya are more responsive to fertilizer application. Phosphorus being one of the primary plant nutrient plays a key role in the plant metabolism. The deficiency of phosphorus decreased the yield of crop up to the extent of 10-15 percent (Shenoy and Kalagandi, 2005). Keeping in view, the present investigation was undertaken to study the effect of fly ash and phosphorous levels on the performance of raya.

\section{Materials and Methods}

The field experiment was conducted at experimental area of agriculture research farm of Guru Kashi University, Talwandi Sabo (Bathinda) during rabi 2018-19. The farm is located at $29^{\circ} 57 \mathrm{~N}$ latitude and $75^{\circ} 7 \mathrm{E}$ longitude and altitude of 213 meters above the sea level as per are extreme. The maximum temperature of about $45^{\circ} \mathrm{C}$ is achieved during month of May and June during the year, while freezing temperature accompanied by frost occurrence may be recorded in the months of December and January in this region. The monsoon generally starts in the first week of July. The treatment consists of two levels of fly ash (main plot) control and fly ash 10t/ha and four levels of phosphorus 15, 30 and 45 $\mathrm{kg} / \mathrm{ha} \mathrm{P}_{2} \mathrm{O}_{5}$ and replicated it thrice in split plot design.

\section{Results and Discussion}

\section{Growth parameters of raya}

The maximum plant height $(189.5 \mathrm{~cm})$ was recorded with fly ash (10 t/ha) application which was significantly higher than control (Table 1). Application of phosphorus increased the plant height. The maximum plant height $(191.7 \mathrm{~cm})$ was recorded with 45 $\mathrm{kg} \quad \mathrm{P}_{2} \mathrm{O}_{5} / \mathrm{ha}$ application which was significantly higher as compared to other phosphorus levels. The interaction effect between the fly ash and phosphorus levels on plant height was significant and maximum plant height $(194.5 \mathrm{~cm})$ was recorded with fly ash (10 t/ha) in combination with $45 \mathrm{~kg}$ $\mathrm{P}_{2} \mathrm{O}_{5} /$ ha application as compared to other treatment combination. Similar results were also reported by Kene et al., (1991) and Gangwal et al., (2011).

Similarly, application of fly ash showed significant effect on other growth parameters of plant. The maximum number of branches/plant (13.2) and leaf area index (4.26) were recorded with fly ash (10 t/ha) application (Table 1). However, the phosphorus and the interaction effect between fly ash and phosphorus levels on number of branches/plant and leaf area index was nonsignificant. Similar results were also reported by Dash et al., (2009).

The maximum dry matter accumulation (87.1 q/ha) was recorded with fly ash (10 t/ha) application which was significantly higher than control (Table 1). Application of phosphorus increased the dry matter accumulation of plant and maximum dry matter accumulation (90.2 q/ha) was observed 
with $45 \mathrm{~kg} \quad \mathrm{P}_{2} \mathrm{O}_{5} /$ ha application which was significantly higher as compared to other phosphorus levels. Similar results were also reported by Patel (2000) and Kene et al., (1991).

Table.1 Effect of fly ash and phosphorous levels on plant height, number of branches, dry matter and leaf area index in raya

\begin{tabular}{|c|c|c|c|c|}
\hline Treatment & Plant height (cm) & $\begin{array}{c}\text { Number of } \\
\text { branches/plant }\end{array}$ & $\begin{array}{c}\text { Dry matter } \\
\text { accumulation (q/ha) }\end{array}$ & $\begin{array}{c}\text { Leaf area } \\
\text { index }\end{array}$ \\
\hline Fly ash levels (t/ha) & \multicolumn{5}{|c|}{} \\
\hline Control & 185.7 & 11.6 & 78.0 & 3.70 \\
\hline $\mathbf{1 0}$ t/ha & 189.5 & 13.2 & 87.1 & 4.26 \\
\hline LSD (0.05\%) & 1.5 & 1.1 & 1.8 & 0.04 \\
\hline Phosphorus levels (kg/ha) & 182.3 & 11.4 & 72.5 & 3.30 \\
\hline $\mathbf{0}$ & 187.1 & 12.1 & 80.2 & 3.70 \\
\hline $\mathbf{1 5}$ & 188.8 & 12.9 & 86.6 & 4.20 \\
\hline $\mathbf{3 0}$ & 191.7 & 13.0 & 90.2 & NS \\
\hline $\mathbf{4 5}$ & 1.2 & $\mathrm{NS}$ & 0.9 & \\
\hline LSD (0.05\%) & & & & \\
\hline
\end{tabular}

Table.2 Effect of fly ash and phosphorous levels on yield attributing characters in raya

\begin{tabular}{|c|c|c|c|}
\hline Treatment & No. of siliquae/plant & $\begin{array}{c}\text { Number of } \\
\text { seeds/siliquia }\end{array}$ & 1000-seed weight (g) \\
\hline \multicolumn{4}{|l|}{ Fly ash levels (t/ha) } \\
\hline Control & 324.1 & 11.6 & 4.10 \\
\hline 10 t/ha & 404.5 & 12.3 & 4.21 \\
\hline LSD $(0.05 \%)$ & 22.3 & 0.4 & 0.03 \\
\hline \multicolumn{4}{|c|}{ Phosphorus levels (kg/ha) } \\
\hline $\mathbf{0}$ & 290.4 & 11.2 & 3.90 \\
\hline 15 & 354.8 & 11.8 & 4.12 \\
\hline 30 & 394.7 & 12.2 & 4.23 \\
\hline 45 & 417.2 & 12.5 & 4.34 \\
\hline LSD (0.05\%) & 13.0 & 0.3 & 0.09 \\
\hline
\end{tabular}

Table.3 Effect of fly ash and phosphorous levels on seed yield in raya

\begin{tabular}{|c|c|c|c|c|c|}
\hline \multirow{2}{*}{$\begin{array}{c}\text { Fly ash levels } \\
\text { (t/ha) }\end{array}$} & \multicolumn{5}{|c|}{ Seed yield (kg/ha) } \\
\hline Phosphorus levels (kg/ha) \\
\hline $\mathbf{0}$ & 0 & 15 & 30 & 45 & Mean \\
\hline Mean & 1904 & 2215 & 2324 & 2398 & 2210 \\
\hline LSD (0.05\%) & 1950 & 2406 & 2511 & 2581 & 2362 \\
\hline & 1927 & 2310 & 2417 & 2489 & \\
\hline & Fly ash & & Phosphorus & Fly ash x Phosphorus \\
\hline
\end{tabular}


Table.4 Effect of fly ash and phosphorous levels on stover yield and harvest index in raya

\begin{tabular}{|c|c|c|}
\hline \multicolumn{1}{|c|}{ Treatment } & Stover yield(kg/ha) & Harvest index (\%) \\
\hline Fly ash levels (t/ha) & \multicolumn{2}{|c|}{} \\
\hline Control & 7601 & 22.4 \\
\hline $\mathbf{1 0}$ t/ha & 8512 & 21.6 \\
\hline LSD (0.05\%) & 153 & 0.3 \\
\hline Phosphorus levels (kg/ha) & & \\
\hline $\mathbf{0}$ & 7058 & 21.4 \\
\hline $\mathbf{1 5}$ & 7826 & 22.6 \\
\hline $\mathbf{3 0}$ & 8467 & 22.2 \\
\hline $\mathbf{4 5}$ & 8825 & 22.0 \\
\hline LSD (0.05\%) & 75 & NS \\
\hline
\end{tabular}

\section{Yield attributes of raya}

The fly ash application also showed significant effect on various yield attributes of raya (Table 2). The increase in number of siliquae per plant, number of seeds per siliqua and 1000 seed weight was recorded and was $404.5,12.3$ and $4.20 \mathrm{~g}$, respectively with fly ash (10 t/ha) application. Similarly, the phosphorus application significantly increased the yield attributing parameters and application of $45 \mathrm{~kg} \mathrm{P}_{2} \mathrm{O}_{5} / \mathrm{ha}$ resulted as increase in number of siliquae per plant (417.2), number of seeds per siliqua (12.5) and 1000 -seed weight (4.3 gm) as compared to other phosphorus levels. However, the interaction effect between fly ash and phosphorus levels on 1000-grain weight was non-significant. Similar results were also reported by Thanunathan et al., (2001), Khafi et al., (1997) and Singh et al., (2014).

\section{Productivity of raya}

The fly ash increased the seed yield of raya and maximum seed yield (2362 kg/ha) was obtained with fly ash (10 t/ha) application which was 6.8 percent over control (Table 3). In case of phosphorus, significantly higher grain yield $(2489 \mathrm{~kg} / \mathrm{ha})$ was recorded at $45 \mathrm{~kg}$ $\mathrm{P}_{2} \mathrm{O}_{5} /$ ha applications compared to other phosphorus levels. The percent increase in seed yield with $45 \mathrm{~kg} \mathrm{P}_{2} \mathrm{O}_{5} /$ ha application was 29.1, 7.7 and 3.1 percent over control, 15 and $30 \mathrm{~kg} \mathrm{P}_{2} \mathrm{O}_{5} /$ ha respectively. The interaction effect between fly ash and phosphorus levels was significant and maximum seed yield (2581 kg/ha) was obtained with fly ash (10 $\mathrm{t} / \mathrm{ha}$ ) in combination with $45 \mathrm{~kg} \mathrm{P}_{2} \mathrm{O}_{5} / \mathrm{ha}$ application as compared to other treatment combinations. Similar trend was observed in stover yield (Table 4). The stover yield (8512 $\mathrm{kg} / \mathrm{ha}$ ) was significantly increased with application of fly ash @10 t/ha. Application of phosphorus resulted in higher stover yield and the maximum stover yield $(8825 \mathrm{~kg} / \mathrm{ha})$ was recorded at $45 \mathrm{~kg} \quad \mathrm{P}_{2} \mathrm{O}_{5} /$ ha application. There was significant interaction between fly ash and phosphorus levels on stover yield and the maximum stover yield $(9603 \mathrm{~kg} / \mathrm{ha})$ was obtained with fly ash (10 t/ha) in combination with $45 \mathrm{~kg} \mathrm{P}_{2} \mathrm{O}_{5} /$ ha application as compared to other treatment combinations. However, application of phosphorus alone and in combination with fly ash showed nonsignificant effect on percent harvest index. Similar results were also reported by Bhari et al (2000), Patel (2000) and Rajkumar (2000).

In conclusion, application of fly ash @ 10 t/ha significantly increased the growth and yield attributes of raya and gave $6.8 \%$ higher seed yield over control. The phosphorus application significantly increased the growth 
and yield attributes resulting percent increase in seed yield to the extent of 29.1, 7.7 and $3.1 \%$ over control, 15 and $30 \mathrm{~kg} \mathrm{P}_{2} \mathrm{O}_{5} / \mathrm{ha}$, respectively. It is concluded that application of 10 t/ha fly ash in combination with $45 \mathrm{~kg}$ $\mathrm{P}_{2} \mathrm{O}_{5} /$ ha gave maximum seed yield of raya. These findings can be useful for improving the production of raya in south-west Punjab.

\section{References}

Bhari, M.A., N.R., Siag, R.K. and Mann, P.S. (2000). Response of Indian mustard (Brassica juncea L.) to nitrogen and phosphorus on torripsamments of North-Western Rajasthan. Indian Journal of Agronomy 45 (4): 746-51.

Dash, S., Sahoo, S. and Sahoo, M. (2009). Effect of fly ash on growth and yield of mustard. International Journal of Applied Environmental Sciences pp. 1617-1629.

Gangwal, T.V., Patel, M.V. and Yadav, N.J. (2011). Effect of phosphorus, sulphur and phosphorus solubilizing bacteria on yield, nutrient uptake and soil fertility after harvest of mustard (Brassica juncea L.). Indian Journal of Fertilizer 7: 32-40.

Kene, D.R., Hanjewar, S.A., Ingaole, B.M. and Chapale S.D. (1991). Effect of application of fly ash on physicchemical properties of soil. Journal of
Soils and Crops 1(1):11-18.

Khafi, H.R., Porwal, B.L., Mathukia, R.K. and Malavia, D.D. (1997). Effect of nitrogen phosphorus and foliar applied chemicals on Indian mustard (Brassica juncea L.). Indian Journal of Agronomy 42(2): 152-54.

Patel, S.R. (2000). Effect of nitrogen and phosphorus levels on growth, yield and quality of toria (Brassica compestris L.) under irrigated condition. Crop Research 15:26-30.

Rajkumar, G.R., (2000). Effect of fly ash on growth and yield of crops, nutrient uptake and soil properties. Ph. D. thesis, University of agricultural Sciences, Dharwad, India. Shenoy, V.V. and Kalagudi, G.M. (2005). Enhancing plant phosphorus use efficiency for suitable cropping. Biotechnology Advances 23: 501-513.

Singh, R., Singh, Kumar, A. and Kumar, P. (2014). Performance of Indian mustard (Brassica juncea L.) in response to integrated nutrient management. Journal of Agriculture Research 1(1): 9-12.

Thanunathan, K., Imayavarambarn, V., Singaravel, $\mathrm{R}$ and Kandasamy, $\mathrm{S}$. (2001). Effect of fly ash on growth, yield and nutrient uptake of sesame. Sesame and safflower newsletter 16:4245.

\section{How to cite this article:}

Lovedeep Singh and Balwinder Singh Dhillon. 2020. Effect of Fly Ash and Phosphorus Levels on Growth and Productivity of Raya (Brassica juncea L.). Int.J.Curr.Microbiol.App.Sci. 9(10): 362-366. doi: https://doi.org/10.20546/ijcmas.2020.910.045 